\title{
Correction: Cerebral ischemia induces microvascular pro-inflammatory cytokine expression via the MEK/ERK pathway
}

Aida Maddahi ${ }^{1,2}$, Lars Edvinsson ${ }^{1,2^{*}}$

We wish to clarify in results page 4 , line 22 of our study [1]; that the information on infarct volume and neurology score after MCAO was taken from our previous study [2].

\section{Author details}

'Division of Vascular Research, BMC, Lund University, Lund, Sweden.

Department of Internal Medicine, Institute of Clinical Sciences, Lund University, Lund, Sweden.

Received: 2 February 2011 Accepted: 21 February 2011

Published: 21 February 2011

\section{References}

1. Maddahi A, Edvinsson L: Cerebral ischemia induces microvascular pro-inflammatory cytokine expression via the MEK/ERK pathway. J Neuroinflammation 7:14.

2. Maddahi A, Edvinsson L: Enhanced expressions of microvascular smooth muscle receptors after focal cerebral ischemia occur via the MAPK MEK/ ERK pathway. BMC Neurosci 2008, 9:85.

doi:10.1186/1742-2094-8-18

Cite this article as: Maddahi and Edvinsson: Correction: Cerebral ischemia induces microvascular pro-inflammatory cytokine expression via the MEK/ERK pathway. Journal of Neuroinflammation 2011 8:18.

* Correspondence: lars.edvinsson@med.lu.se

${ }^{1}$ Division of Vascular Research, BMC, Lund University, Lund, Sweden

Full list of author information is available at the end of the article

Submit your next manuscript to BioMed Central and take full advantage of:

- Convenient online submission

- Thorough peer review

- No space constraints or color figure charges

- Immediate publication on acceptance

- Inclusion in PubMed, CAS, Scopus and Google Scholar

- Research which is freely available for redistribution

Submit your manuscript at www.biomedcentral.com/submit
() Biomed Central 